\title{
Experimental results and modeling of poultry carcass cooling by water immersion
}

\author{
Resultados experimentais e modelagem do resfriamento de carcaças de frango por imersão em água
}

\author{
Bruno Augusto Mattar CARCIOFI ${ }^{1}$, João Borges LAURINDO ${ }^{1 \star}$
}

\begin{abstract}
Poultry carcasses have to be chilled to reduce the central breast temperatures from approximately 40 to $4{ }^{\circ} \mathrm{C}$, which is crucial to ensure safe products. This work investigated the cooling of poultry carcasses by water immersion. Poultry carcasses were taken directly from an industrial processing plant and cooled in a pilot chiller, which was built to investigate the influence of the method and the water stirring intensity on the carcasses cooling. A simplified empiric mathematical model was used to represent the experimental results. These results indicated clearly that the understanding and quantification of heat transfer between the carcass and the cooling water is crucial to improve processes and equipment. The proposed mathematical model is a useful tool to represent the dynamics of carcasses cooling, and it can be used to compare different chiller operational conditions in industrial plants. Therefore, this study reports data and a simple mathematical tool to handle an industrial problem with little information available in the literature.
\end{abstract}

Keywords: poultry processing; heat transfer; water immersion; experiments; mathematical modeling.

\section{Resumo}

As carcaças de aves devem ser rapidamente resfriadas reduzindo a temperatura do centro do músculo peitoral de aproximadamente 40 a $4{ }^{\circ} \mathrm{C}$, o que é crucial para garantir inocuidade do produto. Este trabalho avaliou o resfriamento de carcaças de frango através da imersão em água. As carcaças foram coletadas diretamente da linha de processamento industrial e resfriadas em um tanque piloto de resfriamento construído para avaliar a influência do método e da intensidade da agitação da água no resfriamento das carcaças. Um modelo matemático simplificado foi utilizado para representar os resultados experimentais. Estes resultados indicaram claramente que a compreensão e a quantificação da transferência de calor entre as carcaças e a água de resfriamento são essenciais para a melhoria dos processos e equipamentos. O modelo matemático proposto é uma ferramenta útil para representar a dinâmica de resfriamento das carcaças, podendo ser utilizada para comparar diferentes equipamentos e condições operacionais nas plantas industriais. Assim, este trabalho contribui com dados e com uma ferramenta matemática para tratar um recorrente problema industrial com poucas informações disponíveis na literatura.

Palavras-chave: processamento de frango; transferência de calor; imersão em água; experimentos; modelagem matemática.

\section{Introduction}

Cooling is one of most common thermal processes used to improve the quality and safety of food products and to extend their shelf life (WANG; SUN, 2003). In industrial processing of poultry, immediately after slaughter, bleeding, hot water immersion, feather withdraw and viscera withdraw, poultry carcasses have to be chilled to reduce their temperature from approximately 40 to $4{ }^{\circ} \mathrm{C}$, which contributes to ensure safe products. During the cooling of poultry carcasses, the highest temperature is located in the breast geometric center, which is the parameter to be checked to evaluate the cooling process efficacy (JAMES et al. 2006).

Some kinds of industrial systems used to chill poultry carcasses have been reported by Savell, Mueller and Baird (2005). Water immersion, water spraying, and air blast are the three most common methods used for this purpose. Immersion chilling is a relatively low cost and fast cooling technique largely used in South and North America in countries such as the USA and Brazil, two of the biggest poultry producers in the word. In this system, poultry carcasses are forced to move through stainless steel tanks containing chilled water or a mixture of ice and water. In these tanks, the carcasses are displaced by means of an endless screw in counter-current with the cooling water flow (JAMES et al., 2006; CARCIOFI; LAURINDO, 2007). In European countries, the air cooling of poultry carcasses is more common because of the policies that restrict the usage of immersion chilling (YOUNG; SMITH, 2004; JAMES et al., 2006).

The USA poultry industries routinely use this rapid chilling process because the United States Department of Agriculture, Food Safety and Inspection Service, demands the chilling of carcasses below $4.4^{\circ} \mathrm{C}$ until 4 hours postmortem (SAVELL; MUELLER; BAIRD, 2005). In Brazil, the Federal Agriculture Department demands the usage of at least two chiller tanks for cooling poultry carcass by water immersion. The first tank is used for washing and pre-cooling the carcasses and operates with water at temperature lower than $16^{\circ} \mathrm{C}$, which must be changed to a rate sufficient to guarantee the use of $1.5 \mathrm{~L}$ of water per carcass. In the second tank, the cooling water temperature must be below $4{ }^{\circ} \mathrm{C}$, and its changing rate should guarantee the use of at least $1 \mathrm{~L}$ of water per carcass (CARCIOFI; LAURINDO, 2007).

The cooling rate is influenced by the size, shape, and fat of the carcass, as well as by the temperature and flow pattern 
(and stirring level) of water inside the tanks. In air chillers, the cooling rate depends on the air relative humidity and flow conditions (SAVELL; MUELLER; BAIRD 2005). Landfeld and Houska (2006) used a metallic "chicken" as a simplified physical model to estimate the convective heat coefficients in an air blast cooling tunnel, as well as to verify the influence of evaporative cooling on this parameter. They reported values of convective heat transfer coefficient of about $50 \mathrm{Wm}^{-2} \mathrm{~K}^{-1}$ between the metallic sample and the cooling media. When the evaporative cooling was taken in account (from experimental mass loss data during cooling) to correct the values of the heat transfer coefficients, they found coefficient values of about $19 \mathrm{Wm}^{-2} \mathrm{~K}^{-1}$ for 0.42 mass transfer factor. Another versatile experimental device was reported by Santos et al. (2007) to determine heat transfer coefficients inside air blast tunnels. This device could be adapted for use in immersion tanks.

James et al. (2006) reported data about the influence of chilling parameters (operating costs, weight loss or gain, and chilling time) and chilling methods (immersion, spray/ evaporative, and air chilling) on product safety (microbiology) and quality (flavor, appearance, and texture). According to these authors, the time taken to chill a carcass is the critical parameter for the design of any chilling system. They reported a few results for time-temperature of poultry carcass in different immersion chilling systems, which are presented briefly on Table 1.

Cook and Sair (1938 apud JAMES et al., 2006), proposed Equation 1 to predict cooling times of poultry carcasses chilled by air blast. This equation was based on a large number of experimental data of poultry carcasses chilling, carcass masses, and air temperature, but it does not include air velocities, details about carcasses hanging, etc.

$t^{*}=-5+6.23 \log _{10}\left(T_{i}-T_{\infty-a i r}\right)+1.156 \mathrm{~W}$

where $t^{*}$ is the time (hours) to cool the carcass to $2^{\circ} \mathrm{F}$ above the air temperature, $T$ is the initial carcass temperature $\left({ }^{\circ} \mathrm{F}\right)$, $T_{\infty \text {-air }}$ is the air temperature, and $W$ is the carcass mass (pounds).

The objective of this study was to investigate the influence of water stirring, carcass mass, and carcass initial temperature on its cooling rate and propose an empirical model to predict its time-temperature evolution for different operational conditions and carcasses weight.

\section{Materials and methods}

It is difficult to perform accurate experiments to obtain time-temperature evolutions of poultry carcasses in industrial chillers because the operational conditions cannot be strictly controlled and sometimes they can disturb the production itself. Moreover, regular temperature sensors can move or even be dropped due to the strong contact among the carcasses and between the carcass and equipment during the displacement of the carcasses inside the chiller. Thus, the experiments were performed in a pilot chiller.

\subsection{Pilot chiller}

A pilot chiller was built near an industrial chiller in a plant that process poultry in Brazil. This pilot chiller, sketched in Figure 1, was a rectangular stainless steel tank with dimensions $1 \times 0.915 \times 0.540 \mathrm{~m}$, with water recirculation by means of a centrifuge pump (WEG, $3 \mathrm{hp}-36 \mathrm{~m}^{3} / \mathrm{hour}-3.8 \mathrm{bar}$, Joinville, Brazil) or air injection at its bottom. The control of water recirculation and air injection was performed with valves and the water and air flow was determined by specific rotameters for water and air, respectively.

Carcass samples were hung in the pilot chiller on shackles, for 15 carcasses, and remained immersed in water without direct contact with the tank or with each other.

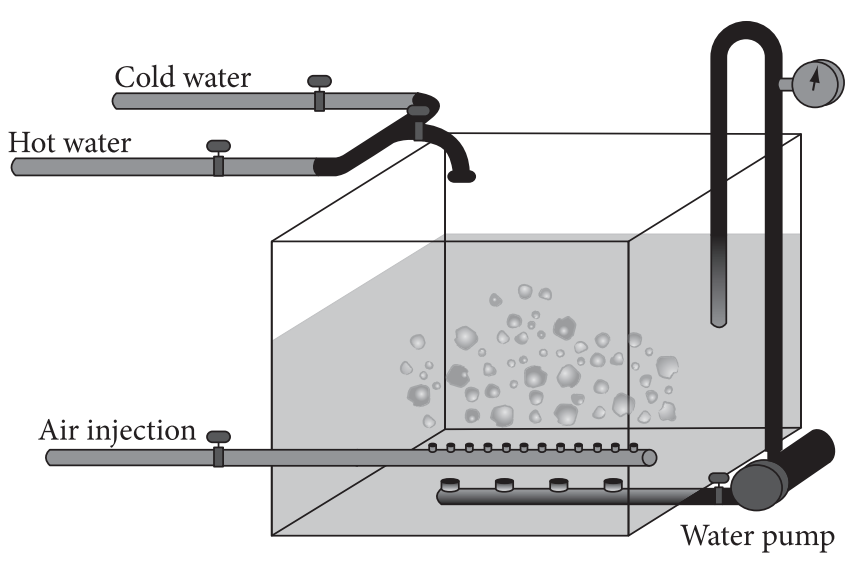

Figure 1. Sketch of the pilot chiller with water recirculation or air injection at its bottom.

Table 1. Cooling times of poultry carcasses by water immersion.

\begin{tabular}{|c|c|c|c|c|c|}
\hline \multirow[t]{2}{*}{ Carcass type } & \multirow{2}{*}{$\begin{array}{l}\text { Weight } \\
(\mathrm{kg})\end{array}$} & \multirow[t]{2}{*}{ Chilling method } & \multicolumn{2}{|c|}{ Temperature $\left({ }^{\circ} \mathrm{C}\right)$} & \multirow{2}{*}{$\begin{array}{c}\text { Time } \\
\text { (second) }\end{array}$} \\
\hline & & & Start & Finish & \\
\hline Broiler eviscerated & $2.5-3.5$ & Immersion in ice/water at $0{ }^{\circ} \mathrm{C}$ & 40 & 10 & 7560 \\
\hline Broiler & 1.33 & 50:50 ice water & & $2-4$ & 1800 \\
\hline Broiler & $1.36-1.47$ & Immersion in ice/water at $0^{\circ} \mathrm{C}$ & & 4 & 4800 \\
\hline Broiler & & Immersion chiller, conventional counter flow & 39.6 & 7 & $<5400$ \\
\hline Broiler & 0.9 & $0^{\circ} \mathrm{C}$ slush ice & & 4.5 & 3000 \\
\hline Broiler & 1.1 & $0^{\circ} \mathrm{C}$ water & & 4.5 & 3600 \\
\hline Broiler & 0.9 & $-18^{\circ} \mathrm{C}$ brine & & 4.5 & 1440 \\
\hline Fowl & 2.0 & $0^{\circ} \mathrm{C}$ slush ice & & 4.5 & 5400 \\
\hline Fowl & 1.9 & $0^{\circ} \mathrm{C}$ slush ice & & 4.5 & 6000 \\
\hline Fowl & 1.6 & $-5^{\circ} \mathrm{C}$ brine & & 4.5 & 2280 \\
\hline
\end{tabular}




\subsection{Poultry carcasses selection}

Poultry carcasses were taken directly from the processing line, after viscera withdraw and fast washing operations, just before entering the industrial cooling (before the feed of the first industrial chiller). The carcasses temperatures were then approximately $40{ }^{\circ} \mathrm{C}$. The selected carcasses did not present rips or wounds in the skin and they were double-checked to avoid the presence of viscera that had not been removed in the industrial process line.

Carcasses weight ranged between 1.605 and $2.094 \mathrm{~kg}$, values determined by a $0.001 \mathrm{~kg}$ precise scale (Toledo, model 2096H/1, São Bernardo do Campo, Brazil). After this selection and weighing, the carcass samples were taken to the pilot chiller. After the essays the carcasses were discarded.

\subsection{Water conditions}

Three different experimental stirring conditions were evaluated: no agitation (NA), water recirculation (WR, $8 \mathrm{~m}^{3}$ of water per hour), and injection of compressed air (IA, $2.4 \mathrm{~m}^{3}$ of air per hour). The average water temperature was $1^{\circ} \mathrm{C}$ for all cases.

\subsection{Temperature measurements}

The transient temperatures were determined through two Pt-100 sensors (precision of $0.5^{\circ} \mathrm{C}$ ) connected to a data acquisition system (Temprecord International Limited, model Multi-Trip, Greenmount Auckland, New Zealand). These sensors were directed towards the geometric center of the poultry carcasses (perforating the skin and penetrating the poultry breast muscle into its center) and towards the cutaneous regions. Temperature data were recorded every 10 seconds and loaded into an interface connected to a PC. Measurements of time-temperature evolutions of 20 carcasses were performed for each different water stirring condition.

\subsection{A simplified mathematical model to carcass cooling}

The determination of the transient temperatures field in a poultry carcass submitted to immersion cooling is not a simple problem, mainly because carcasses have complex geometry and regions with different compositions (skin, breast muscle, thigh muscle, fat, bone, etc.). Moreover, the carcasses have their moisture continuously increased during the cooling immersion process (DUFOUR; RENOU, 2002; JAMES et al. 2006; CARCIOFI; LAURINDO, 2007). Hence, the only carcass' data that can be used accurately is its initial weight.

In this context, a suitable mathematical model to predict the carcasses cooling time must consider the influences of heat transfer conditions at the interface water-carcass (stirring level and water temperature), the average thermophysical properties of the carcasses, and their mass. A simplified model, given by Equation 2, is proposed to represent the experimental data of carcass cooling. This equation is useful to correlate the carcass' temperature evolution as a function of its initial temperature $\left(T_{i}\right)$, process time $(t)$, temperature of cooling water $\left(T_{\infty}\right)$, range of carcass weight and convective heat transfer coefficient inside the immersion tank. The $W$ parameter is the carcass mass, whereas $B$ parameter is a kind of overall heat transfer coefficient, and it depends on the average value of the heat transfer coefficient between the carcasses and cooling water $(h)$ and on the carcass superficial area $(A)$, which are unknown variables. The relation $B / c W$ has rate units, $\mathrm{s}^{-1}$. In this study, the carcasses' mean specific heat $(c)$ was considered $3.5 \mathrm{~kJ} \cdot \mathrm{kg}^{-1}{ }^{\circ} \mathrm{C}$ (FAO, 2008).

$T=\exp \left[-\left(\frac{B}{c W}\right) t\right]\left(T_{i}-T_{\infty}\right)+T_{\infty}$

This empiric equation takes into account the carcass' size (from $W$ ) and the heat transfer parameters and conditions (from $B$ and $c$ ). Therefore, the estimation of $B$ was carried out from the experimental data of carcasses cooling under previously given process conditions (ranges of carcasses weights and levels of water stirring). The software Statistica ${ }^{\varpi} 6.0$ for Windows ${ }^{\oplus}$ (Statsoft, Tulusa, UK) was used for that purpose.

The estimation of $B$ leads to an equation that is useful to represent the cooling rates of these geometrically complex products inside a given water-chiller. Thus, Equation 2 is a kind of operational equation, which can be applied to represent the different operational conditions used in carcasses chiller tanks. Furthermore, the model can be used to compare different chiller operational conditions in industrial plants.

\section{Results and discussion}

\subsection{Carcasses' cooling curves}

Typical time-temperature evolutions of carcasses submitted to immersion cooling are shown in Figure 2. The carcasses took about 3600 seconds to have their central temperatures decreased from approximately 42 to about $4{ }^{\circ} \mathrm{C}$, under IA condition. Under NA conditions, for the same time, the carcasses had their temperatures reduced to approximately $6^{\circ} \mathrm{C}$; situation in which the difference of $2{ }^{\circ} \mathrm{C}$ (between 4 and $6^{\circ} \mathrm{C}$ ) is not negligible because the water

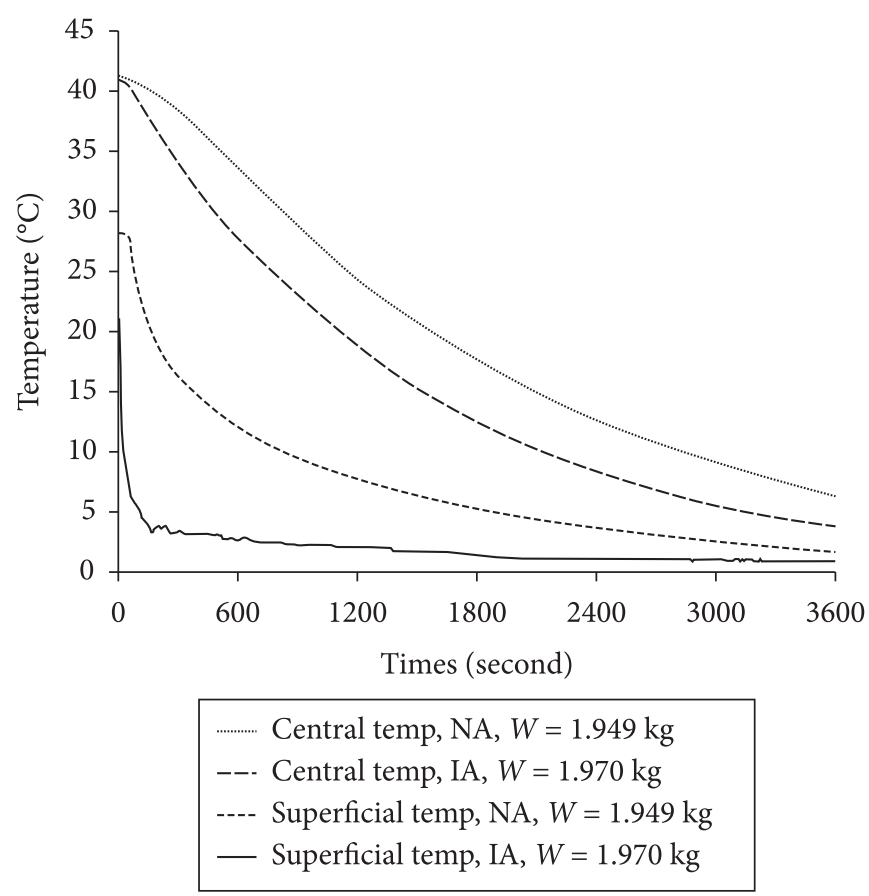

Figure 2. Time-temperature evolutions of the geometric center and surface (under the skin) of poultry carcasses submitted to immersion cooling in water at $1^{\circ} \mathrm{C}$. (low values of $B$ ). 
temperature is about $1{ }^{\circ} \mathrm{C}$ leading, to small heat transfer rates. In addition, the carcasses superficial temperatures were reduced much quickly under IA conditions (to $4{ }^{\circ} \mathrm{C}$ in 180 seconds) than under NA conditions (to about $4{ }^{\circ} \mathrm{C}$ in 2280 seconds). The results presented in Figure 2 show the strong influence of water stirring on the heat transfer process, and they indicate that the understanding and quantification of the convective heat transfer between the carcasses and water inside the tanks is crucial for designing better processes and equipment.

The average values of carcasses temperatures (determined from cooling assays with 20 poultry carcasses) in the beginning and end of the cooling process, as well as the temperature variation between these two instants, at the carcasses geometric center, are shown in Table 2 . These data also showed clearly

Table 2. Average values and standard deviations (sd) of the carcasses temperatures in the beginning and end (after 3600 seconds) of the cooling process and the variations of carcasses central temperatures, between these two instants, for the three process conditions (NA, WR and IA).

\begin{tabular}{cccc}
\hline Operational condition & Initial temperature $\pm \mathrm{sd}\left({ }^{\circ} \mathrm{C}\right)$ & $\begin{array}{c}\text { Temperature after } 3600 \text { seconds } \\
\pm \mathrm{sd}\left({ }^{\circ} \mathrm{C}\right)\end{array}$ & $\begin{array}{c}\text { Temperature variation } \pm \text { sd }\left({ }^{\circ} \mathrm{C}\right) \\
\text { NA }\end{array}$ \\
WR & $38.3 \pm 1.3$ & $7.2 \pm 0.9$ & $31.0 \pm 1.5$ \\
IA & $39.5 \pm 0.7$ & $5.0 \pm 1.1$ & $34.5 \pm 1.2$ \\
\hline
\end{tabular}

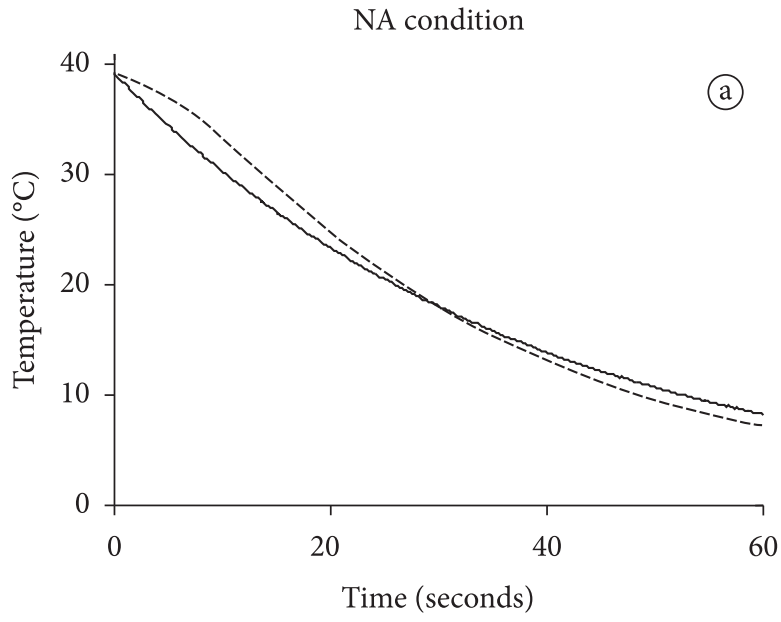

--- Experimental _ Simulated

IA condition

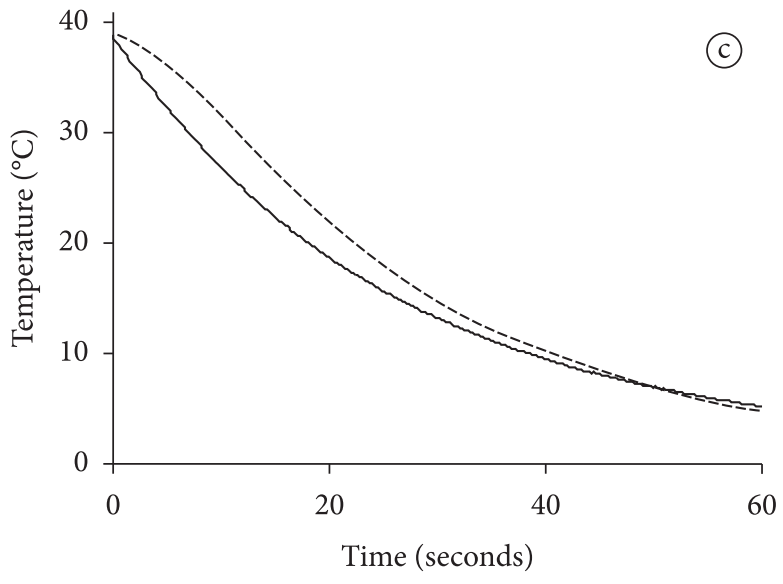

--- Experimental _ Simulated

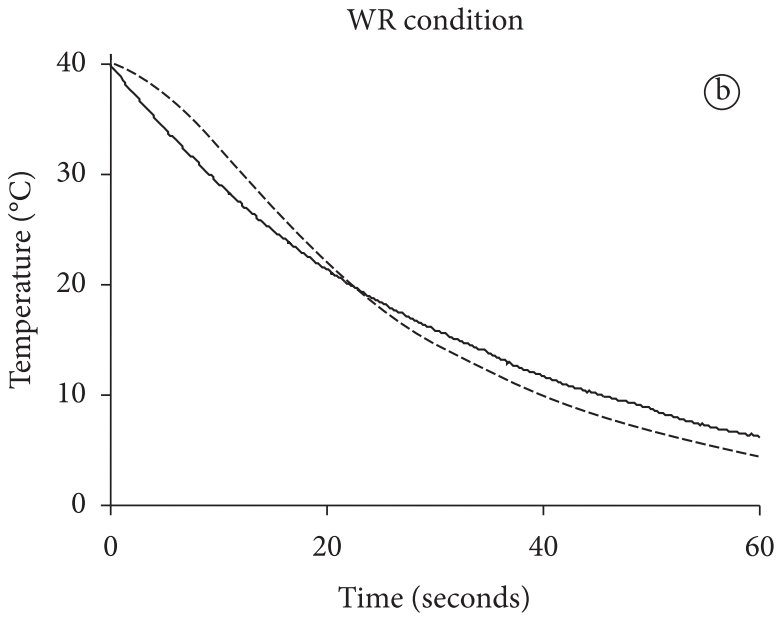

--- Experimental _ Simulated

Simulations for NA, WR and IA conditions

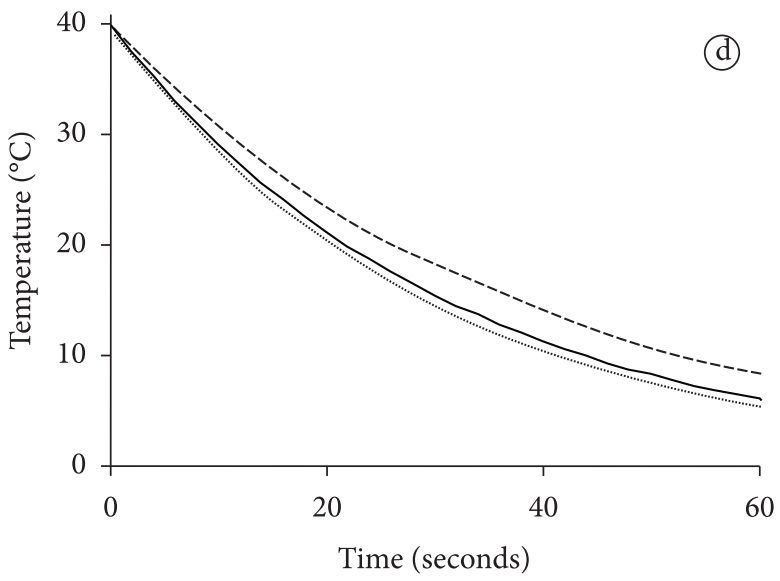

--- NA - WR ……. IA

Figure 3. Time-temperature evolutions of the geometric center of poultry carcasses submitted to immersion cooling in water at $1{ }^{\circ} \mathrm{C}$. a) experimental and simulated data for NA conditions and carcass mass $=2017 \mathrm{~kg}$; b) experimental and simulated data for WR conditions and carcass mass $=1998 \mathrm{~kg} ; \mathrm{c}$ ) experimental and simulated data for AI conditions and carcass mass $=1970 \mathrm{~kg}$ and d) comparison between simulated curves for NA, WR and AI conditions for carcass mass $=2000 \mathrm{~kg}$, initial temperature of the carcass geometric center $=40^{\circ} \mathrm{C}$, and cooling water temperature $=0{ }^{\circ} \mathrm{C}$. 
the influence of water stirring on carcasses cooling, and they presented bigger variations of central temperature for WR and IA operational conditions.

\subsection{Estimation of $B$ values from cooling experimental data}

Table 3 shows the values of $B$ estimated for the three operational conditions from the data of twenty carcasses for each experimental condition. The standard deviations and the significance levels found for $B$ were very good. The values of the correlation coefficients of the fitted model (Equation 2) were also very good. The mean values of the prediction errors shown on Table 3 are the differences between experimental temperatures and those values predicted by Equation 2, with the correspondent $B$ value. For each operational condition, the average error was calculated for data from 20 poultry carcasses (360 time-temperature data for each carcass). The highest $B$ value was found for AI conditions, as expected, since $B$ depends directly on the convective heat transfer values.

Equation 2, and prediction mean errors for each water condition.

Table 3. Values of $B$ and their significance level (p-level), correlation coefficients $\left(\mathrm{R}^{2}\right)$ of the fits with

\begin{tabular}{ccccc}
\hline $\begin{array}{c}\text { Operational } \\
\text { condition }\end{array}$ & $\begin{array}{c}B \\
\left(10^{-2} \mathrm{~kg} / \text { minute }\right)\end{array}$ & p-level & $\mathrm{R}^{2}$ & $\begin{array}{c}\text { Average error } \\
\pm \mathrm{sd}\left({ }^{\circ} \mathrm{C}\right)\end{array}$ \\
\hline NA & 5.3 & $<10^{-5}$ & 0.989 & $1.1 \pm 0.8$ \\
WR & 6.3 & $<10^{-5}$ & 0.984 & $1.5 \pm 1.0$ \\
AI & 6.8 & $<10^{-5}$ & 0.985 & $1.5 \pm 1.0$ \\
\hline
\end{tabular}

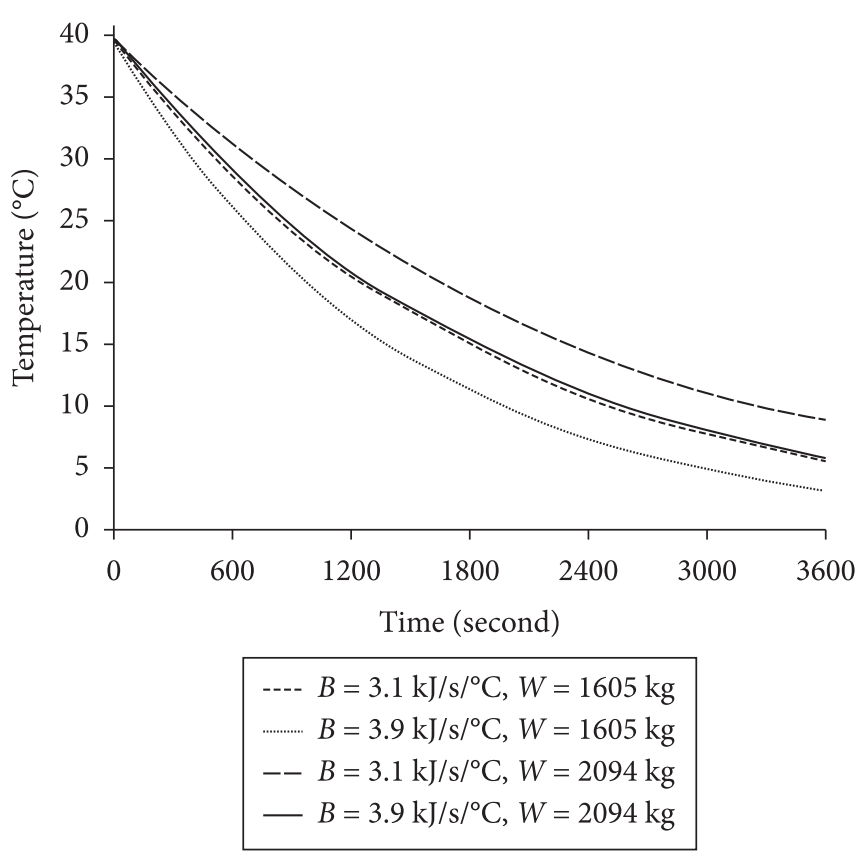

Figure 4. Simulation results of the influence of carcass mass and stirring level on carcasses cooling rates.
Illustrative comparisons between experimental and simulated time-temperature data are presented in Figure 3a, b, c for NA, WR, and AI conditions respectively. Despite its simplicity, the mathematical model was able to predict satisfactorily the time-temperature evolution of the poultry carcasses submitted to different cooling conditions characterized by the parameter $B$. The differences between experimental and simulated results of the beginning of carcasses cooling are explained by the simplicity of the mathematical model used to simulate the process. This model cannot take into account the influence of heat conduction effects. However, the main purpose of the proposed mathematical model is to predict carcasses cooling time.

Figure $3 \mathrm{~d}$ shows the comparison among the simulations performed for the three operational conditions, using the $B$ values shown in Table 3, for carcass mass $=2.000 \mathrm{~kg}$, initial temperature of carcass $=40^{\circ} \mathrm{C}$, and water temperature $=0^{\circ} \mathrm{C}$. Except for the beginning of the cooling process, the simulated curves mimic well the different carcasses time-temperature evolutions for the operational conditions NA, WR and IA.

Figure 4 shows the simulation results of the influence of carcass mass and stirring level on the carcass cooling rate. For the carcasses mass range investigated in this work (between 1.600 and $2.100 \mathrm{~kg}$ ), the simulation results indicate that the final temperature was about $5.6^{\circ} \mathrm{C}$ for $1.6 \mathrm{~kg}$ carcasses and about $8.9^{\circ} \mathrm{C}$ for carcasses with $2.1 \mathrm{~kg}$, for NA conditions. When the AI conditions were considered, these temperatures were about 3.2 and $5.8^{\circ} \mathrm{C}$, respectively. These results indicate that, in any case, it is very important to avoid the cooling of carcasses with a wide distribution of weights since it will lead to heterogeneous cooling. Quantitatively, it was shown the importance of water agitation to ensure faster carcass cooling and indicated that, even if cooling rate is very dependent on heat diffusion inside the carcass, the convective heat transfer resistance cannot be neglected.

Figure 5 shows the simulation results of the influence of stirring heterogeneities inside the immersion tank on the cooling of a $2100 \mathrm{~kg}$ carcass. From two arbitrary cases of stirring heterogeneities [case a): low stirring level in the first section of the tank and high stirring level in the second part and case b): periodic heterogeneities] used in the simulations, it was possible to conclude that a homogeneous water agitation must be guaranteed inside the tank, to avoid stagnation zones with low heat transfer coefficients.

\section{Conclusions}

The results presented in this work indicate clearly that the understanding and quantification of the heat transfer between carcasses and cooling water inside tanks is crucial to improve processes and equipment used for the chilling of poultry carcasses. Surprisingly, few data and analyzes are available in the literature about this subject. Moreover, due to the complexity of the system formed by carcasses and stirred water, few studies have analyzed this process by means of heat transfer models. Surely, such complex 

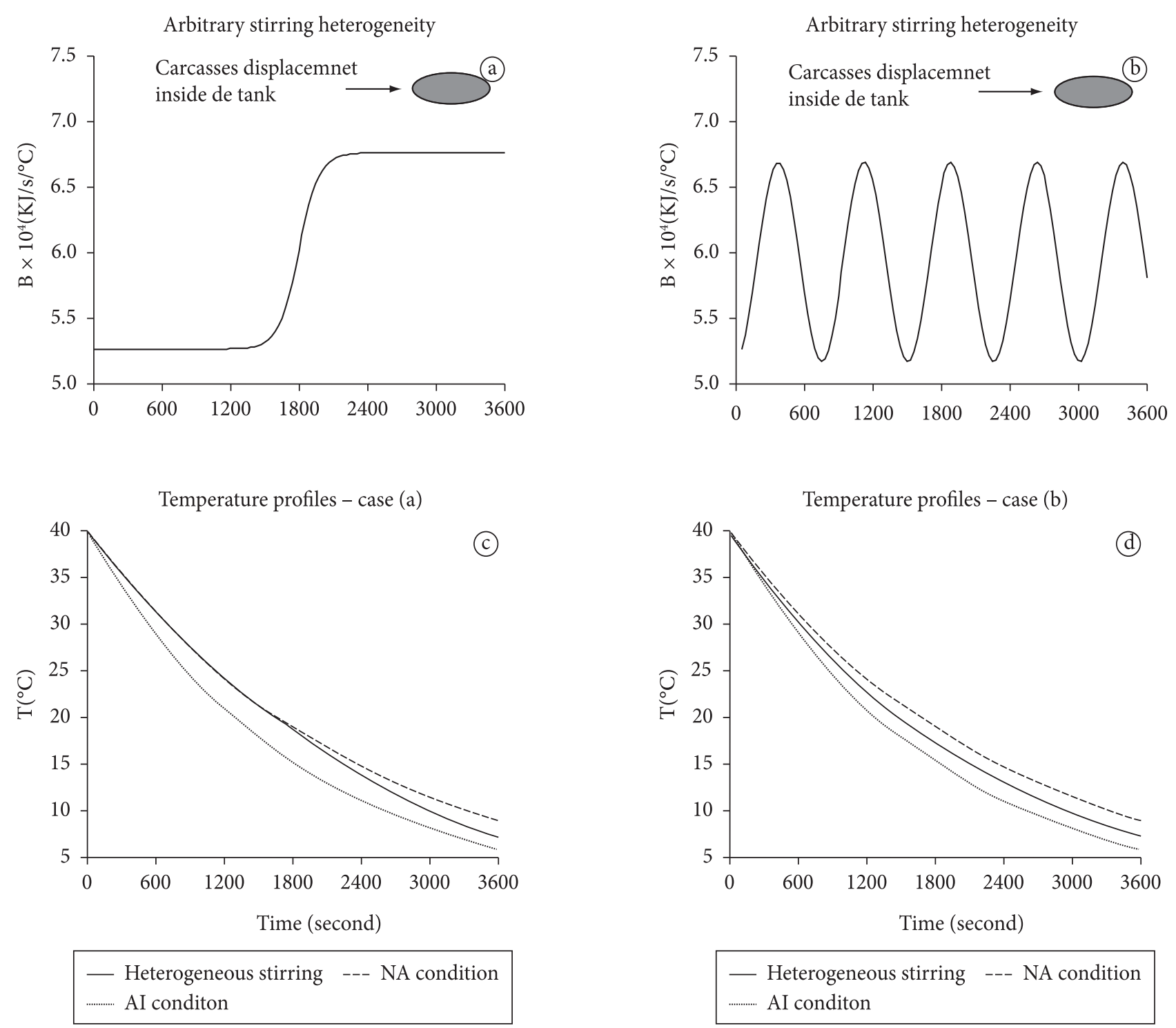

Figure 5. Simulation results of the influence of stirring heterogeneities in the tanks on the carcasses cooling rates: a) and b) arbitrary stirring heterogeneities inside the tank; c) and d) time-temperature evolutions of a $2.100 \mathrm{~kg}$ poultry carcass.

system would be analyzed by means of numerical simulations that could take into account the complexity of the carcass geometry, but this is a difficult task, which needs knowledge of mathematical and numerical tools that are not simple to use.

Despite its simplicity, the mathematical model presented in this study can be used to analyze carcasses time-temperature evolutions during cooling. The model can be used to compare different chiller operational conditions in industrial plants. Therefore, the experiments need to be performed to estimate $B$ values under the operational conditions in each industrial plant.

\section{References}

CARCIOFI, B. A. M.; LAURINDO, J. B. Water uptake by poultry carcasses during cooling by water immersion. Chemical Engineering and Processing, v. 46, n. 5, p. 444-450, 2007.
DUFOUR, E.; RENOU, J. P. Propriétés structurantes de l'eau dans les produits à structure cellulaire. muscle, viande et produits carnés. In: LE MESTE, M.; LORIENT, D.; SIMATOS, D. (Eds.). Propriétés de l'eau dans les aliments. Lavoisier: Tec \& Doc, 2002. p. 159-188.

FOOD AND AGRICULTURE ORGANIZATION OF THE UNITED NATIONS - FAO. Base de datos. In: ORGANIZACIÓN DE LAS NACIONES UNIDAS PARA LA AGRICULTURA Y LA ALIMENTACIÓN. Oficina Regional para América Latina y el Caribe. Ciudad de Panamá, 2008. Disponível em: <http://www.rlc. fao.org>. Acesso em: 25 jan. 2008.

LANDFELD, A.; HOUSKA, M. Prediction of heat and mass transfer during passage of the chicken through chilling tunnel. Journal of Food Engineering, v. 72, n. 1, p. 108-112, 2006.

JAMES, C. et al. The primary chilling of poultry carcasses - a review. International Journal of Refrigeration, v. 29, n. 6, p. 847-862, 2006. 
SANTOS, C. A. et al. Determination of heat transfer coefficient in cooling-freezing tunnels using experimental time temperature data. Journal of Food Process Engineering, v. 30, n. 6, p. 717-728, 2007.

SAVELL, J. W.; MUELLER, S. L.; BAIRD, B. E. The chilling of carcasses. Meat Science, v. 70, n. 3, p. 449-459, 2005.
YOUNG, L. L.; SMITH, D. P. Moisture retention by water- and airchilled chicken broilers during processing and cutup operations. Poultry Science, v. 83, n. 1, p. 119-122, 2004.

WANG, L.; SUN, D. W. Recent developments in numerical modelling of heating and cooling in the food industry - a review. Trends in Food Science \& Technology, v. 14, p. 408-423, 2003. 